\title{
Evaluation of limited sampling strategies for tacrolimus
}

\author{
Robert A. M. Op den Buijsch • Afke van de Plas • \\ Leo M. L. Stolk • Maarten H. L. Christiaans • \\ Johannes P. van Hooff • Nas A. Undre • \\ Marja P. van Dieijen-Visser • Otto Bekers
}

Received: 13 June 2007 / Accepted: 23 July 2007 / Published online: 22 August 2007

(C) Springer-Verlag 2007

\begin{abstract}
Objective In literature, a great diversity of limited sampling strategies (LSS) have been recommended for tacrolimus monitoring, however proper validation of these strategies to accurately predict the area under the time concentration curve $\left(\mathrm{AUC}_{0-12}\right)$ is limited. The aim of this study was to determine whether these LSS might be useful for AUC prediction of other patient populations.

Methods The LSS from literature studied were based on regression equations or on Bayesian fitting using MWPHARM 3.50 (Mediware, Groningen, the Netherlands). The performance was evaluated on 24 of these LSS in our population of 37 renal transplant patients with known AUCs. The results were also compared with the predictability of the regression equation based on the trough concentrations $\mathrm{C}_{0}$ and $\mathrm{C}_{12}$ of these 37 patients. Criterion was an absolute prediction error (APE) that differed less than $15 \%$ from the complete $\mathrm{AUC}_{0-12}$ calculated by the trapezoidal rule.

Results Thirteen of the 18 (72\%) LSS based on regression analysis were capable of predicting at least $90 \%$ of the 37
\end{abstract}

R. A. M. Op den Buijsch $(\bowtie) \cdot$ M. P. van Dieijen-Visser •

O. Bekers

Department of Clinical Chemistry, University Hospital Maastricht, P.O. Box 5800, 6202 AZ Maastricht, The Netherlands

e-mail: RBUY@klinchem.azm.nl

A. van de Plas $\cdot$ L. M. L. Stolk

Department of Clinical Pharmacy, University Hospital Maastricht, Maastricht, The Netherlands

M. H. L. Christiaans • J. P. van Hooff

Department of Internal Medicine, University Hospital Maastricht, Maastricht, The Netherlands

N. A. Undre

Astellas,

Munich, Germany individual $\mathrm{AUC}_{0-12}$ within an $\mathrm{APE}$ of $15 \%$. Additionally, all but three LSS examined gave a better prediction of the complete $\mathrm{AUC}_{0-12}$ in comparison with the trough concentrations $\mathrm{C}_{0}$ or $\mathrm{C}_{12}$ (mean 62\%). All six LSS based on Bayesian fitting predicted $<90 \%$ of the 37 complete $\mathrm{AUC}_{0-12}$ correctly (mean 67\%).

Conclusions The present study indicated that implementation of LSS based on regression analysis could produce satisfactory predictions although careful evaluation is necessary.

Keywords Tacrolimus $\cdot$ Limited sampling strategy · Trough level $\cdot \mathrm{AUC}_{0-12}$

\section{Introduction}

The calcineurin-inhibitor tacrolimus, used widely after organ transplantation, has a narrow therapeutic index and highly variable pharmacokinetic characteristics. Close monitoring of the drug concentration is required to achieve an optimum efficiency by minimizing the risk of subtherapeutic and toxic blood concentrations. Efficacy and side effects of tacrolimus are highly correlated with the area under the time concentration curve $\left(\mathrm{AUC}_{0-12}\right)$ [1]. Elevated tacrolimus concentrations may lead to severe side effects such as nephrotoxicity, neurotoxicity and hyperglycaemia [2-4], while subtherapeutic tacrolimus concentrations increase the risk of transplant rejection enormously [5-7].

The most exact way to monitor the total tacrolimus exposure is by creating 12-h pharmacokinetic profiles, which implies that the tacrolimus concentration should be measured at at least six different time points. The $\mathrm{AUC}_{0-12}$ can then be calculated according to the trapezoidal rule using the tacrolimus concentrations measured at different 
time points. Since recording a complete 12 -h pharmacokinetic profile for every patient is not feasible in clinical practice, traditionally many transplant centres have used tacrolimus trough $\left(\mathrm{C}_{0}\right)$ concentrations to estimate the tacrolimus exposure. Although tacrolimus $\mathrm{C}_{0}$ concentrations are generally considered to be a good indication of the total systemic drug exposure [1, 8], its usefulness in differentiating graft rejection episodes from nephrotoxicity has been questioned [6,9-11]. Recently, the correlation between individual tacrolimus concentrations and $\mathrm{AUC}_{0-12}$ has been studied in kidney [12-18], liver [19], heart [20, 21] and lung [22] transplant recipients. In these studies, a poor association was found between the tacrolimus $\mathrm{C}_{0}$ concentrations and the $\mathrm{AUC}_{0-12}$, while tacrolimus concentrations measured at other time points showed much better correlations with the $\mathrm{AUC}_{0-12}$. Additionally, strategies have been developed that included a limited number of sampling time points within a short time post-dose, the so-called limited sampling strategies (LSS). Several two- and threetime-point sampling strategies showed a high correlation with the $\mathrm{AUC}_{0-12}$ in published studies and were able to predict the $\mathrm{AUC}_{0-12}$ more accurately than the $\mathrm{C}_{0}$ concentration alone [12, 15-18, 20, 22].

Based on the number of published studies regarding LSS for tacrolimus, there seems to be a growing interest for non$\mathrm{C}_{0}$ concentration measurements as an indicator of betweenpatient variability and as a guide for dose adjustments. Most of these studies recommend different LSS, but these strategies have not been validated with an independent population. Ting et al. [23] recently reported that validation of the different LSS with an independent transplant population is an absolute prerequisite. The question was whether the LSS described in literature could be used in other centres with different populations. Predictive value of LSS from literature was evaluated using our own renal post-transplant group of 37 patients with known AUCs. Also the predictive value of trough levels $\left(\mathrm{C}_{0}\right.$ and $\left.\mathrm{C}_{12}\right)$ determined in our own population was investigated.

\section{Materials and methods}

\section{Patient population}

In total, 37 Caucasian renal transplant recipients for whom a complete 12-h time tacrolimus concentration curve had been determined in a past clinical trial were included in this study (Table 1). The transplant recipients underwent a renal transplantation at least 1 year ago. Patients taking medication known to interact with tacrolimus, who suffered from gastro-intestinal or liver disease, pre-transplantation diabetes mellitus or other disorders that could have altered the absorption of tacrolimus were excluded from this study as illustrated in Table 1.
Table 1 Demographic characteristics of renal-transplant recipients

\begin{tabular}{|c|c|}
\hline Demographic characteristics & $\begin{array}{l}\text { Patients } \\
(n=37)\end{array}$ \\
\hline Gender (male/female) & $24 / 13$ \\
\hline Age (years, mean $\pm \mathrm{SD}$ ) & $51.3 \pm 10.9$ \\
\hline Length $(\mathrm{cm}$, mean $\pm \mathrm{SD})$ & $174 \pm 8.4$ \\
\hline Weight $(\mathrm{kg}$, mean $\pm \mathrm{SD})$ & $77.4 \pm 13.5$ \\
\hline Body mass index $\left(\mathrm{kg} / \mathrm{m}^{2}\right.$, mean $\left.\pm \mathrm{SD}\right)$ & $25.6 \pm 3.42$ \\
\hline \multicolumn{2}{|l|}{ Primary kidney disease $(n)$} \\
\hline Glomerulonephritis & 1 \\
\hline Chronic pyelonephritis & 2 \\
\hline IgA nephropathy & 4 \\
\hline Hypertensive nephropathy & 7 \\
\hline Diabetes mellitus nephropathy & 0 \\
\hline Polycystic kidney disease & 8 \\
\hline Unknown & 4 \\
\hline Other & 11 \\
\hline \multicolumn{2}{|l|}{ Transplantation number $(n)$} \\
\hline First & 30 \\
\hline Second & 6 \\
\hline Third or more & 1 \\
\hline Tacrolimus mono therapy $(n)$ & 29 \\
\hline Tacrolimus dose $\left(\mathrm{mg} \mathrm{kg}^{-1}\right.$ day $^{-1}$, mean $\left.\pm \mathrm{SD}\right)$ & $0.054 \pm 0.029$ \\
\hline $\mathrm{C}_{0}(\mathrm{ng} / \mathrm{mL}$, mean $\pm \mathrm{SD})$ & $6.59 \pm 1.39$ \\
\hline $\mathrm{AUC}_{0-12}(\mathrm{ng} \times \mathrm{h} / \mathrm{mL}$, mean $\pm \mathrm{SD})$ & $122.5 \pm 31.1$ \\
\hline $\mathrm{C}_{\max }(\mathrm{ng} / \mathrm{mL}$, mean $\pm \mathrm{SD})$ & $20.9 \pm 6.5$ \\
\hline $\mathrm{T}_{\max }(\mathrm{h}$, mean $\pm \mathrm{SD})$ & $1.24 \pm 0.43$ \\
\hline Use of azothioprine/MMF/rapamycine/steroids & $3 / 4 / 0 / 2$ \\
\hline Time since transplantation (days, mean and range) & $\begin{array}{l}1,542(453- \\
4,128)\end{array}$ \\
\hline $\begin{array}{l}\text { Haemoglobin }(\mathrm{mmol} / \mathrm{L} \text {, ref. M: 8.2-11.0, } \\
\text { F: 7.3-9.7) }\end{array}$ & $8.52 \pm 0.83$ \\
\hline $\begin{array}{l}\text { Haematocrit fraction (ref. M: } 0.41-0.52 \text {, } \\
\text { F: } 0.36-0.48 \text { ) }\end{array}$ & $0.41 \pm 0.04$ \\
\hline ALAT (units/L, ref. M: <45, F: <35) & $24 \pm 13$ \\
\hline ASAT (units/L, ref. M: $<35, \mathrm{~F}:<30$ ) & $17 \pm 10$ \\
\hline Serum albumin $(\mathrm{g} / \mathrm{L}$, ref. $34-45)$ & $37.0 \pm 3.84$ \\
\hline $\begin{array}{l}\text { Serum creatinine }(\mu \mathrm{mol} / \mathrm{L} \text {, ref. M: } 71-110 \text {, } \\
\text { F: } 53-97)\end{array}$ & $128 \pm 29$ \\
\hline $\begin{array}{l}\text { Creatinine clearance (Cockcroft-Gault; } \mathrm{mL} / \mathrm{min} \text {, } \\
\text { ref. } 90-140 \text { ) }\end{array}$ & $58.4 \pm 26.6$ \\
\hline
\end{tabular}

Ref. are the reference values applied in the Clinical Chemistry and Haematology Laboratory of the University Hospital in Maastricht. $M$ Male, $F$ female, $M M F$ mycophenolate mofetil

Prior to the blood sample collection, there was no tacrolimus dose change for at least 1 week. After overnight fasting, the blood samples were collected immediately before $\left(\mathrm{C}_{0}\right)$ and $0.5\left(\mathrm{C}_{0.5}\right), 1\left(\mathrm{C}_{1}\right), 2\left(\mathrm{C}_{2}\right), 3\left(\mathrm{C}_{3}\right), 4\left(\mathrm{C}_{4}\right)$, $5\left(\mathrm{C}_{5}\right), 7.5\left(\mathrm{C}_{7.5}\right)$ and $12\left(\mathrm{C}_{12}\right) \mathrm{h}$ after the morning tacrolimus administration. Patients were not allowed to take food until $1 \mathrm{~h}$ after ingesting the tacrolimus dose and were advised to avoid grapefruit intake to prevent alterations in the tacrolimus metabolism. Demographic as well 
as clinical data were determined at the time of recording the 12-h time tacrolimus concentration curve. The study was performed in accordance with the Declaration of Helsinki and its amendments. The protocol was approved by the local Medical Ethics Committee and written informed consent for participation in this study was obtained from all patients.

\section{Determination of tacrolimus concentrations}

The tacrolimus blood concentrations were determined in ethylene diamine tetra-acetic acid (EDTA) whole blood, using a method based on high-pressure liquid chromatography tandem mass spectrometry (HPLC-MS/MS). The assay is linear from 1 to $300 \mu \mathrm{g} / \mathrm{l}$. Intra-assay precision and accuracy were $3.4,2.2$, and $3.0 \%$ and 102,94 and $94 \%$ respectively at $3.04,6.23$ and $13.0 \mu \mathrm{g} / 1(n=6)$. Inter-assay precision and accuracy were $8.2,5.2$, and $4.6 \%$ and 102,94 and $93 \%(n=9)$ respectively. Lower limit of quantification was $1.0 \mu \mathrm{g} / \mathrm{l}$. The laboratory participates in the International Tacrolimus Proficiency Testing Scheme.

\section{Limited sampling strategies investigated}

In our opinion, a suitable limited sampling strategy for tacrolimus should consist of two or three time concentration points within a short time post-dose $(\leq 4 \mathrm{~h})$ including a trough level. We selected 24 LLS from the literature [12, $15,16,18,20,22]$. Eighteen of these strategies were based on regression analysis $[12,16,18,20,22]$, and six other strategies were based on Bayesian fitting [15]. Also strategies based on the tacrolimus $\mathrm{C}_{0}$ and $\mathrm{C}_{12}$ concentrations were developed for our own renal transplant patient population and compared with above-mentioned LSS.

\section{Pharmacokinetics and statistical analysis}

The area under the tacrolimus time concentration curve $\left(\mathrm{AUC}_{0-12}\right)$ was calculated from the time versus tacrolimus concentration plot using the linear trapezoidal rule in MWPharm 3.50 (Mediware, Groningen, The Netherlands). The predicted $\mathrm{AUC}_{0-12}\left(\mathrm{AUC}_{\text {pred }}\right)$, calculated with the 24 different LSS, were validated by determining the predictive performance as described by Sheiner and Beal [24]. The percentage of the prediction error $(\mathrm{PE})$ and the percentage of the absolute prediction error (APE) are parameters often used for validation in LSS [12, 14-16, 18, 20, 22]. Given the high pharmacokinetic variability, an APE of less than $15 \%$ was considered clinically acceptable $[16,25,26]$.

Prediction bias was measured as a percentage of the prediction error [PE (\%)] using the following formula:

$$
\mathrm{PE}(\%)=100 \times\left(\mathrm{AUC}_{\text {pred }}-\mathrm{AUC}_{\text {actual }}\right) / \mathrm{AUC}_{\text {actual }}
$$

Prediction precision was measured as a percentage of the APE using the following formula:

$\operatorname{APE}(\%)=100 \times\left|\left(\mathrm{AUC}_{\text {pred }}-\mathrm{AUC}_{\text {actual }}\right)\right| / \mathrm{AUC}_{\text {actual }}$

The variance in the strength of association between the $\mathrm{AUC}_{\text {pred }}$ and the $\mathrm{AUC}_{\text {actual }}$ was reflected by the linear regression coefficient of multiple determination $\left(R^{2}\right)$. All values are expressed as mean \pm SD. All statistical analyses were performed with use of SPSS 12.0 software for windows (Chicago, IL, USA).

\section{Results}

Evaluation of predictive performances of the limited sampling strategies

Table 2 shows an overview of the studies describing the LSS evaluated in the present study. The regression equations and the $R^{2}$ found by the investigators for the evaluated LSS are summarised in Table 3. Table 4 describes the $R^{2}$, which represents the association between $\mathrm{AUC}_{\text {pred }}$ and $\mathrm{AUC}_{\text {actual }}$ and the calculated PE and APE of the 24 evaluated LSS for our 37 pharmacokinetic profiles. Thirteen of the 18 LSS $(72 \%)$ based on regression analysis had a predictivity of $>90 \%$. Additionally, all except three of the LSS examined gave a better prediction of the complete $\mathrm{AUC}_{0-12}$ in comparison with LSS based on a trough concentration $\mathrm{C}_{0}$ and $\mathrm{C}_{12}$ (mean 62\%). Predictivity of all six LSS based on Bayesian fitting was $<90 \%$ (mean $66.8 \%$ ). Additionally, Fig. 1 illustrates an overview of the performances of the 26 LSS evaluated in our wellcharacterized population of renal transplant recipients.

\section{Discussion}

Our results confirm the results of several other studies [12, 14-16, 18, 20,22] that trough concentrations $\mathrm{C}_{0}$ and $\mathrm{C}_{12}$ have a lower predictive value for the complete 12-h AUC than almost all other studied LSS. The predictivity of LSS based on Bayesian estimation of the $\mathrm{AUC}_{\text {actual }}$ was lower than the LSS based on regression analysis. Therefore a trough level and one or two time points in the early phase $(\leq 4 \mathrm{~h})$ post-dose seem not to be sufficient for a Bayesian estimation strategy to fit correctly most of the $\mathrm{AUC}_{0-12}$ and thus predict the complete $\mathrm{AUC}_{0-12}$ reliably. The differences in variability and shape between the curves of posttransplant recipients combined with just two or three sample points might have been caused by the large differences found between the $\mathrm{AUC}_{\text {pred }}$ calculated according to the Bayesian estimation strategy and the complete $\mathrm{AUC}_{\text {actual }}$. 
Table 2 Overview of the characteristics of transplant patients included in the studies that described limited sampling strategies

\begin{tabular}{|c|c|c|c|c|c|c|}
\hline Study & Transplanted organ & $\begin{array}{l}\text { Number } \\
\text { of patients }^{\mathrm{a}}\end{array}$ & $\begin{array}{l}\text { Number of } \mathrm{AUC}_{0-12} \\
\text { curves for validation }\left(\mathrm{I}^{\mathrm{b}} / \mathrm{NI}^{\mathrm{c}}\right)\end{array}$ & $\begin{array}{l}\text { Analytical } \\
\text { method }^{\mathrm{d}}\end{array}$ & $\begin{array}{l}\text { Time since } \\
\text { transplantation }^{\mathrm{e}}\end{array}$ & $\begin{array}{l}\text { Inclusion } \\
\text { criteria }^{\text {f }}\end{array}$ \\
\hline Wong et al. [16] & Kidney & 18 & $0 / 18$ & $\operatorname{Imx}$ II & 2.5 years & 1,2 \\
\hline Aumente Rubio et al. [20] & Heart & 22 & $0 / 25$ & $\operatorname{Imx}$ & $<1$ year & - \\
\hline Pisitkun et al. [18] & Kidney & 15 & $0 / 15$ & $\operatorname{Imx}$ II & 8.7 months & $1,2,3$ \\
\hline Armendariz et al. [12] & Kidney & 22 & $13 / 14$ & $\operatorname{Imx}$ & Unknown & - \\
\hline Scholten et al. [15] & Kidney & 43 & $64 / 20$ & $\operatorname{Imx}$ & Differs $^{\mathrm{g}}$ & 2 \\
\hline Ragette et al. [22] & Lung & 15 & $0 / 31$ & $\operatorname{Imx}$ & 7.3 months & - \\
\hline
\end{tabular}

${ }^{a}$ Number of transplant patients used in the included study for both developing and validating the limited sampling strategies.

${ }^{\mathrm{b}}$ Number of $\mathrm{AUC}_{0-12}$ used for developing the limited sampling strategies.

${ }^{\mathrm{c}}$ Number of independent (I) and dependent (NI) $\mathrm{AUC}_{0-12}$ used in the study to validate the created limited sampling strategies.

${ }^{\mathrm{d}}$ The analytical method used to determine the whole blood tacrolimus concentration.

e The mean time after transplantation.

${ }^{\mathrm{f}}$ The inclusion criteria used for the transplant patients in the different studies. 1 Tacrolimus administrated when patients were in the fasting state, 2 patients selected for using no interfering medication with tacrolimus, 3 patients selected with a normal liver function test.

${ }^{\mathrm{g}}$ Twenty-two pharmacokinetic profiles were obtained within 2 weeks after transplantation, and 42 pharmacokinetic profiles were obtained between 6 and 52 weeks after transplantation.

In contrast to most studies that describe LSS for tacrolimus in literature, we used an HPLC-MS/MS assay to determine the tacrolimus concentration. Because there seems to be a fixed difference of about $15 \%$ between the immunoassay and the HPLC-MS/MS, the prediction will change proportionally, and the predictivity of the LSS will be the same. Also potential interfering drug-drug interactions will have an equal influence on the different

Table 3 Overview of limited sampling strategies and their reported coefficients of correlation $\left(R^{2}\right)$ with the complete tacrolimus $\mathrm{AUC}_{0-12}$

\begin{tabular}{|c|c|c|c|c|}
\hline Equation & Time points & Regression equations & $R^{2}$ & Ref \\
\hline 1. & $\mathrm{C}_{0}$ & $14.550+13.387 \times \mathrm{C}_{0}$ & 0.54 & \\
\hline 2. & $\mathrm{C}_{12}$ & $15.892+17.852 \times \mathrm{C}_{12}$ & 0.79 & \\
\hline $3 .^{\mathrm{a}}$ & $\mathrm{C}_{0}, \mathrm{C}_{2}, \mathrm{C}_{4}$ & $13.3+1.2 \times \mathrm{C}_{0}+2.4 \times \mathrm{C}_{2}+5.6 \times \mathrm{C}_{4}$ & 0.93 & [16] \\
\hline 4. ${ }^{\mathrm{a}}$ & $\mathrm{C}_{2}, \mathrm{C}_{4}$ & $16.2+2.4 \times \mathrm{C}_{2}+5.9 \times \mathrm{C}_{4}$ & 0.93 & {$[16]$} \\
\hline $5 .^{\mathrm{a}}$ & $\mathrm{C}_{0}, \mathrm{C}_{2}, \mathrm{C}_{4}$ & $0.98+4.17 \times \mathrm{C}_{0}+2.29 \times \mathrm{C}_{2}+5.3 \times \mathrm{C}_{4}$ & 0.97 & {$[20]$} \\
\hline 6. & $\mathrm{C}_{0}, \mathrm{C}_{4}$ & $3.75+5.52 \times \mathrm{C}_{0}+6.97 \times \mathrm{C}_{4}$ & 0.95 & {$[20]$} \\
\hline 7. & $\mathrm{C}_{0}, \mathrm{C}_{1}, \mathrm{C}_{2}$ & $-5.496+7.189 \times \mathrm{C}_{0}+2.357 \times \mathrm{C}_{1}+2.131 \times \mathrm{C}_{2}$ & 0.93 & [18] \\
\hline $8 .^{\mathrm{a}}$ & $\mathrm{C}_{0}, \mathrm{C}_{1}, \mathrm{C}_{4}$ & $3.85+3.688 \times \mathrm{C}_{0}+1.355 \times \mathrm{C}_{1}+6.649 \times \mathrm{C}_{4}$ & 0.97 & [18] \\
\hline 9. ${ }^{\mathrm{a}}$ & $\mathrm{C}_{0}, \mathrm{C}_{2}, \mathrm{C}_{4}$ & $-6.103+2.383 \times \mathrm{C}_{0}+1.911 \times \mathrm{C}_{2}+7.582 \times \mathrm{C}_{4}$ & 0.97 & [18] \\
\hline $10 .^{\mathrm{a}}$ & $\mathrm{C}_{1}, \mathrm{C}_{2}, \mathrm{C}_{4}$ & $1.304+0.465 \times \mathrm{C}_{1}+1.636 \times \mathrm{C}_{2}+8.256 \times \mathrm{C}_{4}$ & 0.96 & [18] \\
\hline 11. & $\mathrm{C}_{0}, \mathrm{C}_{1}$ & $9.345+8.408 \times \mathrm{C}_{0}+3.23 \times \mathrm{C}_{1}$ & 0.91 & [18] \\
\hline $12 .^{\mathrm{a}}$ & $\mathrm{C}_{0}, \mathrm{C}_{4}$ & $8.231+2.316 \times \mathrm{C}_{0}+9.636 \times \mathrm{C}_{4}$ & 0.95 & [18] \\
\hline $13 .^{\mathrm{a}}$ & $\mathrm{C}_{1}, \mathrm{C}_{4}$ & $13.114+0.873 \times \mathrm{C}_{1}+9.291 \times \mathrm{C}_{4}$ & 0.95 & [18] \\
\hline $14 .^{\mathrm{a}}$ & $\mathrm{C}_{2}, \mathrm{C}_{4}$ & $-0.192+1.888 \times \mathrm{C}_{2}+8.783 \times \mathrm{C}_{4}$ & 0.96 & [18] \\
\hline $15 .^{\mathrm{a}, \mathrm{b}}$ & $\mathrm{C}_{0}, \mathrm{C}_{1}, \mathrm{C}_{4}$ & $4.5 \times \mathrm{C}_{0}+2 \times \mathrm{C}_{1}+5.5 \times \mathrm{C}_{4}$ & 0.97 & [18] \\
\hline $16^{\mathrm{a}, \mathrm{b}}$ & $\mathrm{C}_{0}, \mathrm{C}_{2}, \mathrm{C}_{4}$ & $5 \times \mathrm{C}_{0}+2 \times \mathrm{C}_{2}+5 \times \mathrm{C}_{4}$ & 0.96 & [18] \\
\hline 17. & $\mathrm{C}_{0}, \mathrm{C}_{1}, \mathrm{C}_{4}$ & $8.90+4.0 \times \mathrm{C}_{0}+1.77 \times \mathrm{C}_{1}+5.47 \times \mathrm{C}_{4}$ & 0.97 & [12] \\
\hline 18. & $\mathrm{C}_{0}, \mathrm{C}_{1}, \mathrm{C}_{3}$ & Bayesian estimation of the actual $\mathrm{AUC}_{0-12}$ & 0.97 & [15] \\
\hline 19. & $\mathrm{C}_{0}, \mathrm{C}_{2}, \mathrm{C}_{3}$ & Bayesian estimation of the actual $\mathrm{AUC}_{0-12}$ & 0.96 & {$[15]$} \\
\hline 20. & $\mathrm{C}_{0}, \mathrm{C}_{2}, \mathrm{C}_{4}$ & Bayesian estimation of the actual $\mathrm{AUC}_{0-12}$ & 0.97 & {$[15]$} \\
\hline 21. & $\mathrm{C}_{0}, \mathrm{C}_{2}$ & Bayesian estimation of the actual $\mathrm{AUC}_{0-12}$ & 0.94 & {$[15]$} \\
\hline 22. & $\mathrm{C}_{0}, \mathrm{C}_{3}$ & Bayesian estimation of the actual $\mathrm{AUC}_{0-12}$ & 0.96 & {$[15]$} \\
\hline 23. & $\mathrm{C}_{0}, \mathrm{C}_{4}$ & Bayesian estimation of the actual $\mathrm{AUC}_{0-12}$ & 0.95 & {$[15]$} \\
\hline $24 .^{\mathrm{a}}$ & $\mathrm{C}_{0}, \mathrm{C}_{2}, \mathrm{C}_{4}$ & $5.87+4.50 \times \mathrm{C}_{0}+1.05 \times \mathrm{C}_{2}+5.87 \times \mathrm{C}_{4}$ & 0.98 & {$[22]$} \\
\hline 25. & $\mathrm{C}_{0}, \mathrm{C}_{4}$ & $1.16+4.41 \times \mathrm{C}_{0}+7.71 \times \mathrm{C}_{4}$ & 0.96 & {$[22]$} \\
\hline $26 .^{\mathrm{a}}$ & $\mathrm{C}_{2}, \mathrm{C}_{4}$ & $24.36+0.97 \times \mathrm{C}_{2}+7.94 \times \mathrm{C}_{4}$ & 0.94 & [22] \\
\hline
\end{tabular}

Limited sample strategies derived from the linear trapezoidal rule and the complete 12-h AUC.

${ }^{\mathrm{a}}$ Limited sampling strategies that are able to predict $90 \%$ of complete $\mathrm{AUC}_{0-12}$ of the renal transplant recipients within the absolute prediction error (APE) of $15 \%$.

${ }^{\mathrm{b}}$ Limited sample strategies derived from the linear trapezoidal rule and the actual $\mathrm{AUC}_{0-12}$. 
Table 4 Evaluation of predictive performance of limited sampling strategies to estimate the complete $\mathrm{AUC}_{0-12}$ in the 37 renal transplant recipients

\begin{tabular}{|c|c|c|c|c|c|}
\hline Equation & Time points & $R^{2}$ & Mean PE (\%) & Mean APE (\%) & $\leq 15 \%{ }^{\mathrm{a}}$ \\
\hline $23 .^{b}$ & $\mathrm{C}_{0}, \mathrm{C}_{4} * *$ & 0.760 & $-14.9 \pm 13.8(-46.0-33.2)$ & $17.9 \pm 9.43(1.12-46.0)$ & $13(35 \%)$ \\
\hline $22 .^{\mathrm{b}}$ & $\mathrm{C}_{0}, \mathrm{C}_{3} * *$ & 0.779 & $-11.5 \pm 14.0(-41.9$ to 33.1$)$ & $15.7 \pm 8.83(2.0-41.9)$ & $21(57 \%)$ \\
\hline 1. & $\mathrm{C}_{0}$ & 0.536 & $2.11 \pm 14.8(-27.1$ to 24.4$)$ & $12.3 \pm 8.22(0.7-27.1)$ & $22(59 \%)$ \\
\hline 11. & $\mathrm{C}_{0}, \mathrm{C}_{1}$ & 0.703 & $6.58 \pm 14.8(-26.5$ to 43.7$)$ & $12.6 \pm 10.1(0.1-43.7)$ & $24(65 \%)$ \\
\hline 2. & $\mathrm{C}_{12}$ & 0.80 & $9.56 \pm 11.6(-12.7$ to 29.9$)$ & $12.0 \pm 8.97(0.3-29.9)$ & $24(65 \%)$ \\
\hline $19 .^{b}$ & $\mathrm{C}_{0}, \mathrm{C}_{2}, \mathrm{C}_{3} * *$ & 0.502 & $-4.44 \pm 17.4(-45.3$ to 50.6$)$ & $13.7 \pm 11.4(0.4-50.6)$ & $25(68 \%)$ \\
\hline $20 .^{\mathrm{b}}$ & $\mathrm{C}_{0}, \mathrm{C}_{2}, \mathrm{C}_{4} * *$ & 0.537 & $-5.11 \pm 16.3(-43.1$ to 50.3$)$ & $12.9 \pm 10.4(0.2-50.3)$ & $28(76 \%)$ \\
\hline $18 .^{\mathrm{b}}$ & $\mathrm{C}_{0}, \mathrm{C}_{1}, \mathrm{C}_{3} * *$ & 0.525 & $9.95 \pm 19.4(-29.7$ to 88.8$)$ & $13.1 \pm 17.4(0.4-88.8)$ & $30(81 \%)$ \\
\hline 25. & $\mathrm{C}_{0}, \mathrm{C}_{4}$ & 0.911 & $-7.83 \pm 6.36(-21.3$ to 2.4$)$ & $8.08 \pm 6.02(0.1-21.3)$ & $30(81 \%)$ \\
\hline 7. & $\mathrm{C}_{0}, \mathrm{C}_{1}, \mathrm{C}_{2}$ & 0.869 & $2.35 \pm 9.96(-17.2$ to 27.3$)$ & $8.03 \pm 6.22(0.0-27.3)$ & $31(84 \%)$ \\
\hline 6. & $\mathrm{C}_{0}, \mathrm{C}_{4}$ & 0.896 & $-5.97 \pm 6.71(-20.1$ to 4.7$)$ & $6.63 \pm 6.04(0.6-20.1)$ & $31(84 \%)$ \\
\hline $21 .^{\mathrm{b}}$ & $\mathrm{C}_{0}, \mathrm{C}_{2} * *$ & 0.802 & $-3.69 \pm 10.2(-19.6$ to 18.6$)$ & $9.10 \pm 5.67(0.4-19.6)$ & $31(84 \%)$ \\
\hline 17. & $\mathrm{C}_{0}, \mathrm{C}_{1}, \mathrm{C}_{4}$ & 0.943 & $5.91 \pm 7.06(-8.8$ to 26.3$)$ & $7.02 \pm 5.93(0.2-26.3)$ & $33(89 \%)$ \\
\hline $15 .^{\mathrm{c}}$ & $\mathrm{C}_{0}, \mathrm{C}_{1}, \mathrm{C}_{4} *$ & 0.934 & $5.00 \pm 7.28(-9.8$ to 25.8$)$ & $6.81 \pm 5.57(0.2-25.8)$ & $34(92 \%)$ \\
\hline 14. & $\mathrm{C}_{2}, \mathrm{C}_{4}$ & 0.964 & $2.28 \pm 6.58(-17.1$ to 16.1$)$ & $5.45 \pm 4.24(0.7-17.1)$ & $35(95 \%)$ \\
\hline 24. & $\mathrm{C}_{0}, \mathrm{C}_{2}, \mathrm{C}_{4}$ & 0.941 & $-4.81 \pm 5.26(-17.3$ to 2.8$)$ & $5.32 \pm 4.73(0.1-17.3)$ & $35(95 \%)$ \\
\hline 13. & $\mathrm{C}_{1}, \mathrm{C}_{4}$ & 0.973 & $6.30 \pm 4.84(-5.9$ to 17.8$)$ & $6.68 \pm 4.28(0.3-17.8)$ & $36(97 \%)$ \\
\hline 8. & $\mathrm{C}_{0}, \mathrm{C}_{1}, \mathrm{C}_{4}$ & 0.967 & $3.37 \pm 5.21(-5.2$ to 17.7$)$ & $4.87 \pm 3.80(0.2-17.7)$ & $36(97 \%)$ \\
\hline 9. & $\mathrm{C}_{0}, \mathrm{C}_{2}, \mathrm{C}_{4}$ & 0.962 & $0.10 \pm 6.37(-16.7$ to 14.7$)$ & $4.71 \pm 4.22(0.3-16.7)$ & $36(97 \%)$ \\
\hline 26. & $\mathrm{C}_{2}, \mathrm{C}_{4}$ & 0.959 & $3.38 \pm 5.24(-7.6$ to 15.5$)$ & $5.20 \pm 3.37(0.0-15.5)$ & $36(97 \%)$ \\
\hline 10. & $\mathrm{C}_{1}, \mathrm{C}_{2}, \mathrm{C}_{4}$ & 0.976 & $3.07 \pm 5.40(-14.9$ to 13.2$)$ & $4.99 \pm 3.64(0.1-14.9)$ & $37(100 \%)$ \\
\hline $16 .^{\mathrm{c}}$ & $\mathrm{C}_{0}, \mathrm{C}_{2}, \mathrm{C}_{4} *$ & 0.953 & $-1.58 \pm 5.29(-14.9$ to 10.1$)$ & $4.00 \pm 3.75(0.0-14.9)$ & $37(100 \%)$ \\
\hline 12. & $\mathrm{C}_{0}, \mathrm{C}_{4}$ & 0.930 & $3.55 \pm 6.30(-9.8$ to 14.3$)$ & $6.29 \pm 3.46(0.1-14.3)$ & $37(100 \%)$ \\
\hline 4. & $\mathrm{C}_{2}, \mathrm{C}_{4}$ & 0.963 & $-1.66 \pm 4.99(-12.0$ to 14.3$)$ & $4.13 \pm 3.20(0.2-14.3)$ & $37(100 \%)$ \\
\hline 5. & $\mathrm{C}_{0}, \mathrm{C}_{2}, \mathrm{C}_{4}$ & 0.959 & $1.33 \pm 5.24(-11.8$ to 14.0$)$ & $4.22 \pm 3.32(0.5-14.0)$ & $37(100 \%)$ \\
\hline 3. & $\mathrm{C}_{0}, \mathrm{C}_{2}, \mathrm{C}_{4}$ & 0.965 & $-0.20 \pm 4.79(-10.4$ to 13.7$)$ & $3.64 \pm 3.06(0.2-13.7)$ & $37(100 \%)$ \\
\hline
\end{tabular}

${ }^{\mathrm{a}}$ Number and percentage of calculated $\mathrm{AUC}_{0-12}$ with a prediction error within $15 \%$.

${ }^{\mathrm{b}}$ Bayesian estimation of the actual $\mathrm{AUC}_{0-12}$.

${ }^{\mathrm{c}}$ Limited sample strategies derived from the linear trapezoidal rule and the actual $\mathrm{AUC}_{0-12}$.

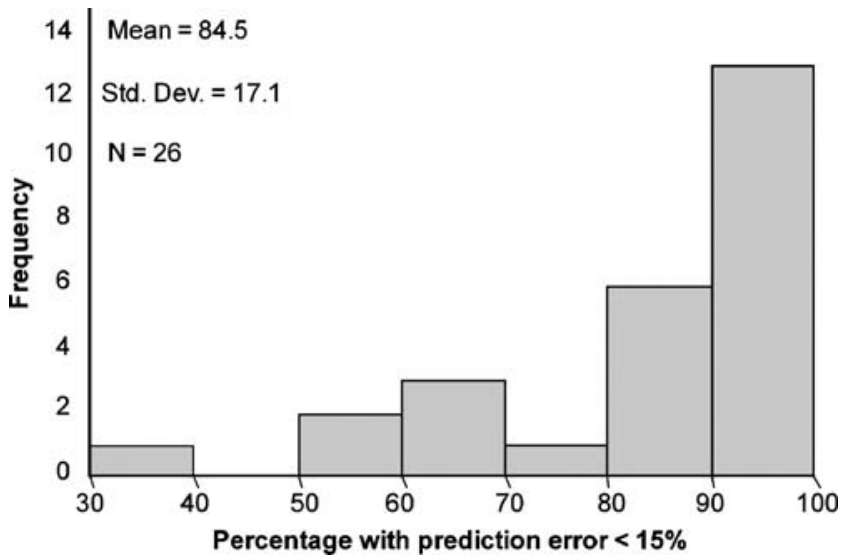

Fig. 1 An overview of the predictive performances of the limited sampling strategies published using 37 different pharmacokinetic profiles recorded in our renal transplant recipients. The number of limited sampling strategies categorized into the percentage of $\mathrm{AUC}_{0-12}$ within a prediction error of $<15 \%$ is plotted on the $x$-axis, the number of limited sampling strategies is plotted on the $y$-axis tacrolimus concentrations, which consequently has no effect on the predictivity of the different LSS.

Ting et al. [23] recently suggested that LSS should only be applied on transplant patient populations that are comparable with the transplant patient population that was used to develop the LSS. However, the renal transplant patient group examined in the present study was not exactly comparable with the transplant patient populations in which the equations for the LSS were developed. For example Aumente Rubio et al. [20] and Ragette et al. [22] used heart and lung transplant recipients respectively to develop and validate their LSS. Despite the fact that the LSS were developed with the pharmacokinetic profiles of patients who underwent a different kind of transplantation, Eqs. (5), (24) and (26) were able to predict at least $90 \%$ of the $\mathrm{AUC}_{0-12}$ within an APE of $15 \%$, which suggests that these LSS are more robust than expected by Ting et al. [23]. Even though LSS gave a better reflection of the tacrolimus exposure, they are currently not often applied by clinical transplant practioners, possibly for logistical and financial reasons. 
In conclusion, after validating several LSS from the literature, the present study indicates that all but three LSS gave a better prediction of the complete $\mathrm{AUC}_{0-12}$ than the trough concentrations $\mathrm{C}_{0}$ or $\mathrm{C}_{12}$. Moreover, LSS could produce satisfactory predictions for $\mathrm{AUC}_{0-12}$ recorded in an independent renal transplant patient population, although further evaluation of their reliability is necessary.

Acknowledgements We would like to thank Mrs Monique Mullens and Mr John Dackus (Department of Internal Medicine, University Hospital Maastricht, the Netherlands) for their excellent work regarding the extensive blood sample collection required to record a pharmacokinetic profile for each renal transplant patient.

\section{References}

1. Mahalati K, Kahan BD (2000) Pharmacological surrogates of allograft outcome. Ann Transplant 5(2):14-23

2. Winkler M, Christians U (1995) A risk-benefit assessment of tacrolimus in transplantation. Drug Saf 12(5):348-357

3. McMaster P, Mirza DF, Ismail T, Vennarecci G, Patapis P, Mayer AD (1995) Therapeutic drug monitoring of tacrolimus in clinical transplantation. Ther Drug Monit 17(6):602-605

4. Staatz CE, Tett SE (2004) Clinical pharmacokinetics and pharmacodynamics of tacrolimus in solid organ transplantation. Clin Pharmacokinet 43(10):623-653

5. Laskow DA, Vincenti F, Neylan JF, Mendez R, Matas AJ (1996) An open-label, concentration-ranging trial of FK506 in primary kidney transplantation: a report of the United States Multicenter FK506 Kidney Transplant Group. Transplantation 62(7):900-905

6. Kershner RP, Fitzsimmons WE (1996) Relationship of FK506 whole blood concentrations and efficacy and toxicity after liver and kidney transplantation. Transplantation 62(7):920-926

7. Undre NA, van Hooff J, Christiaans M, Vanrenterghem Y, Donck J, Heeman U et al (1999) Low systemic exposure to tacrolimus correlates with acute rejection. Transplant Proc 31(1-2):296-298

8. Braun F, Schutz E, Peters B, Talaulicar R, Grupp C, Undre N et al (2001) Pharmacokinetics of tacrolimus primary immunosuppression in kidney transplant recipients. Transplant Proc 33(3):2127-2128

9. Backman L, Nicar M, Levy M, Distant D, Eisenstein C, Renard T et al (1994) Whole blood and plasma levels of FK 506 after liver transplantation: correlation with toxicity. Transplant Proc 26(3):1804

10. Takahara S, Kokado Y, Kameoka H, Takano Y, Jiang H, Moutabarrik A et al (1994) Monitoring of FK 506 blood levels in kidney transplant recipients. Transplant Proc 26(4):2106-2108

11. Winkler M, Ringe B, Rodeck B, Melter M, Stoll K, Baumann J et al (1994) The use of plasma levels for FK 506 dosing in livergrafted patients. Transpl Int 7(5):329-333
12. Armendariz Y, Pou L, Cantarell C, Lopez R, Perello M, Capdevila L (2005) Evaluation of a limited sampling strategy to estimate area under the curve of tacrolimus in adult renal transplant patients. Ther Drug Monit 27(4):431-434

13. Balbontin FG, Kiberd B, Squires J, Singh D, Fraser A, Belitsky P et al (2003) Tacrolimus monitoring by simplified sparse sampling under the concentration time curve. Transplant Proc 35(7):2445-2448

14. Kuypers DR, Claes K, Evenepoel P, Maes B, Coosemans W, Pirenne J et al (2004) Time-related clinical determinants of longterm tacrolimus pharmacokinetics in combination therapy with mycophenolic acid and corticosteroids: a prospective study in one hundred de novo renal transplant recipients. Clin Pharmacokinet 43(11):741-762

15. Scholten EM, Cremers SC, Schoemaker RC, Rowshani AT, van Kan EJ, den Hartigh J et al (2005) AUC-guided dosing of tacrolimus prevents progressive systemic overexposure in renal transplant recipients. Kidney Int 67(6):2440-2447

16. Wong KM, Shek CC, Chau KF, Li CS (2000) Abbreviated tacrolimus area-under-the-curve monitoring for renal transplant recipients. Am J Kidney Dis 35(4):660-666

17. Stolk LM, Van Duijnhoven EM, Christiaans MH, van Hooff JP (2002) Trough levels of tacrolimus. Ther Drug Monit 24(4):573; author reply, 4

18. Pisitkun T, Eiam-Ong S, Chusil S, Praditpornsilpa K, Pansin P, Tungsanga K (2002) The roles of $\mathrm{C} 4$ and AUC0-4 in monitoring of tacrolimus in stable kidney transplant patients. Transplant Proc 34(8):3173-3175

19. Ku YM, Min DI (1998) An abbreviated area-under-the-curve monitoring for tacrolimus in patients with liver transplants. Ther Drug Monit 20(2):219-223

20. Aumente Rubio MD, Arizon del Prado JM, Lopez Malo de Molina MD, Cardenas Aranzana M, Segura Saint-Gerons J, Lopez Granados A et al (2003) Clinical pharmacokinetics of tacrolimus in heart transplantation: new strategies of monitoring. Transplant Proc 35(5):1988-1991

21. Sgrosso JL, Araujo GL, Vazquez MC (2002) Tacrolimus pharmacokinetics in heart transplant. Transplant Proc 34(1):142-143

22. Ragette R, Kamler M, Weinreich G, Teschler H, Jakob H (2005) Tacrolimus pharmacokinetics in lung transplantation: new strategies for monitoring. J Heart Lung Transplant 24(9):1315-1319

23. Ting LS, Villeneuve E, Ensom MH (2006) Beyond cyclosporine: a systematic review of limited sampling strategies for other immunosuppressants. Ther Drug Monit 28(3):419-430

24. Sheiner LB, Beal SL (1981) Some suggestions for measuring predictive performance. J Pharmacokinet Biopharm 9(4):503-512

25. Meier-Kriesche HU, Kaplan B, Brannan P, Kahan BD, Portman RJ (1998) A limited sampling strategy for the estimation of eighthour neoral areas under the curve in renal transplantation. Ther Drug Monit 20(4):401-407

26. David OJ, Johnston A (2001) Limited sampling strategies for estimating cyclosporin area under the concentration-time curve: review of current algorithms. Ther Drug Monit 23(2):100-114 